\author{
St ud i P hilos o p hi c a \\ Wr a t i s l a vi e n s i a \\ vol. XIII, fasc. 4 (2018) \\ DOI: $10.19195 / 1895-8001.13 .4 .3$
}

MAGDALENA HOŁY-€UCZAJ

ORCID: 0000-0001-5860-3638

Wyższa Szkoła Informatyki i Zarządzania w Rzeszowie

\title{
Czy to możliwe, że Heidegger był reistą? Próba rekonstrukcji Heideggerowskiej ontyki
}

Czy ontologia Martina Heideggera ma swoje dopełnienie w postaci ontyki? To pytanie można sformułować również następująco: czy Heideggerowska koncepcja bycia łączy się z określonym ujęciem bytu? W artykule pokażę, że można uznać je za zbliżone do reizmu Tadeusza Kotarbińskiego, który zakładał, że byt to rzecz. Odpowiedź dlaczego tak jest, pozwoli — jak postaram się uzasadnić — odsłonić pewne ukryte założenia dotyczące rozumienia bycia przez Heideggera.

\section{Reizm Kotarbińskiego}

W próbie rekonstrukcji Heideggerowskiej ontyki, jak zaznaczyłam powyżej, odniosę się do koncepcji Tadeusza Kotarbińskiego. Zestawienie nazwisk filozofów reprezentujących dwie obce sobie orientacje filozoficzne może wydawać się nieintuicyjne. Okazuje się jednak, że łączy ich więcej, niż można przypuszczać. Poniższa analiza nie będzie jednak pracą porównawczą. Filozofia Kotarbińskiego stanowi tu ramę dla ujęcia ontyki Heideggera, którą przedstawię jako koncepcję o charakterze reistycznym, starając się równocześnie pokazać, w jaki sposób wiąże się ona z założeniami z jego ontologii.

Konkretyzm Tadeusza Kotarbińskiego jest koncepcją zarówno ontologiczną, jak i semantyczną, która kształtowała się od lat dwudziestych do późnych lat pięćdziesiątych XX wieku. Gdyby chcieć zwięźle opisać jej ewolucję, można by powiedzieć, że początkowo dominowała teza ontologiczna (redukcja kategorii ontologicznych do kategorii rzeczy), później na pierwszy plan wysunęła się teza semantyczna (zalecenie używania wyłącznie nazw konkretnych). Należy jednak podkreślić, że Kotarbiński pomimo akceptacji zarzutów stawianych ontologicznemu reizmowi nigdy z niego nie zrezygnował. Był przekonany, że świat spełnia zasady reizmu, lecz 
przyznawał, że nie ma wystarczającego uzasadnienia dla takiego poglądu ${ }^{1}$. Podzielając metafizyczną intuicję Kotarbińskiego, w niniejszej analizie koncentruję się na reizmie rozumianym jako stanowisko ontologiczne, nie zapominając o jego oczywistym kontekście, którym jest reizm semantyczny.

Fundamentem, na którym wspiera się reizm, jest przekonanie, że istnieją rzeczy i tylko rzeczy ${ }^{2}$. Kotarbiński zakładał, że każdy (rzeczywisty) przedmiot jest rzeczą. Autor Elementów oddalał tautologiczność tej tezy, mówiąc, że przedmiot to najszerzej pojęte coś, rzecz zaś to przedmiot umiejscowiony w czasie i przestrzeni oraz fizykalnie jakiśs ${ }^{3}$. Materialny charakter rzeczy Kotarbiński dookreślał, opisując ją jako rozciągłą oraz stawiającą opór ${ }^{4}$. Do zbioru tak rozumianych rzeczy należy według Kotarbiński człowiek, byty ożywione (zwierzęta, rośliny) oraz nieożywione: naturalne (na przykład kamień) i sztuczne (na przykład zegarek) ${ }^{5}$.

Zdając sobie sprawę z wieloznaczności pojęcia „rzecz”, Kotarbiński uznał, że najtrafniej je zdefiniuje, utożsamiając rzecz z ciałem rozumianym jako konkretne indywiduum. Koncepcja Kotarbińskiego ze względu na swoją oszczędność ontologiczną odrzucała wszelkie dualizmy, w związku z czym na jej gruncie psychika (dusza) jest czymś cielesnym, a ściślej jest tożsama z fragmentem ciała (choć Kotarbiński nie przesądza którym ${ }^{6}$ ). Tak też dla Kotarbińskiego wszystko jest ciałem doznającym lub nie. Z tego powodu filozof określał swoje stanowisko również jako pansomatyzm. Niestety nazwa „ciało” jest problematyczna, ponieważ kojarzy się z żywym organizmem, przez co zawężą się jej znaczenie fizykalne do biologicznego. Z kolei termin „rzecz”, od której pochodzi określenie „reizm”, popada w druga skrajność i jest często utożsamiana wyłącznie z przedmiotami nieożywionymi ${ }^{7}$. Od tych zagrożeń wolne jest pojęcie „,konkret”, na które ostatecznie zdecydował się Kotarbiński, nazywając swoją koncepcję konkretyzmem ${ }^{8}$.

Przeciwieństwem konkretu jest „hipostaza” — główny czarny charakter w systemie Kotarbińskiego ${ }^{9}$. Hipostazy to byty urojone lub pozorne, które według Kotarbińskiego swoją fikcyjną egzystencję zawdzięczają pewnym nawykom językowym. Przykładem hipostaz są cechy (akcydensy). Według Kotarbińskiego nie istnieje okrągłość — jest tylko okrągła pomarańcza. Nie znaczy to oczywiście, że byty dla Kotarbińskiego są bezjakościowe. Twórca konkretyzmu skupionego na jednostkowych bytach materialnych nigdy nie podważał ich zmysłowości. Kotarbiński odmawiał jedynie statusu autonomicznie istniejących bytów przedmiotom innym niż

1 J. Woleński, Kotarbiński, Warszawa 1990, s. 58; E. Grodziński, Tadeusza Kotarbińskiego walka z hipostazami, „Studia Filozoficzne” 7 (1984), s. 86; K. Szaniawski, Filozofia konkretu, „Studia Filozoficzne" 3 (1976), s. 67.

2 T. Kotarbiński, Uwagi na temat reizmu, „Ruch Filozoficzny” 12 (1931), s. 7; K. Szaniawski, Filozofia konkretu..., s. 67.

3 T. Kotarbiński, Fazy rozwojowe konkretyzmu, „Studia Filozoficzne” 1 (1958), s. 233; E. Grodziński, Tadeusza Kotarbińskiego..., s. 86.

${ }^{4}$ T. Kotarbiński, Zasadnicze myśli pansomatyzmu, „Przegląd Filozoficzny” 33 (1934), s. 283.

5 Ibidem.

${ }^{6}$ Ibidem.

7 J. Kozłowski, O reizmie somatycznym Tadeusza Kotarbińskiego, „Zeszyty Naukowe Akademii Górniczo-Hutniczej. Prace Filozoficzne" 27 (1985), s. 29.

8 T. Kotarbiński, Fazy rozwojowe konkretyzmu, passim; J. Woleński, Kotarbiński, s. 43.

${ }^{9}$ E. Grodziński, Tadeusza Kotarbińskiego..., s. 79. 
konkretne indywidua. Dlatego twierdził, że nie istnieje biel ani słodycz, choć mamy biały i słodki cukier. Na tej samej zasadzie Kotarbiński występował przeciw substancjalizowaniu - uznawaniu za byt — szeroko pojętych przedmiotów idealnych: gatunków, relacji, stanów rzeczy, zdarzeń, obrazów wewnętrznych ${ }^{10}$. Nie istnieją myśli — jest tylko Jan, który o czymś myśli; nie istnieje podróż — jest tylko Jan, który podróżuje.

Nominalizm Kotarbińskiego skłonił go także do odrzucenia istnienia czystej materii jako hipostazy. W ten sposób koncepcja Kotarbińskiego to materializm bez materii ${ }^{11}$. Warto $\mathrm{w}$ tym miejscu podkreślić, że pansomatyzm był niechętny mechanicyzmowi ${ }^{12}$. Kotarbiński opisując fizykalność ciał, kładł nacisk na to, że są oporne, a nie tylko bezwładne. Ponadto podkreślał, że granica między przyrodą ożywioną a nieożywioną nie jest wyraźna ${ }^{13}$.

Z kolei w wypadku matematyki Kotarbiński jako nominalista twierdził, że żadna liczba nie jest rzeczą. Arytmetyka w opinii Kotarbińskiego różni się od nauk przyrodniczych nie tym, o czym mówi w ogóle, lecz tym, co mówi o rzeczach ,a mówi mianowicie, że jeżeli takie a takie rzeczy są tak a tak liczne, to takie a ta-

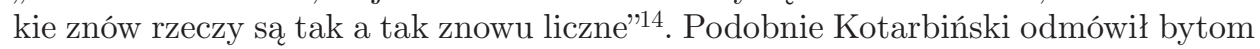
literackim statusu faktycznie istniejących rzeczy. Twierdził, że historyk literatury nie ma do dyspozycji innych obiektów badania niż tylko teksty, ich twórcy i odbiorcy $^{15}$. Skoro nie traktujemy rozmów jako bytów, to dlaczego spisane wypowiedzi miałyby za nie uchodzić?

Wskazane ujęcie literatury, tak jak matematyki, może wydawać się niesatysfakcjonujące. Spotkało się ono, podobnie jak ujęcie przedmiotu badań innych nauk, z żywą krytyką ${ }^{16}$. Inne problemy, w jakie był uwikłany reizm, dotyczą jego semantycznego wymiaru. Przede wszystkim reizm miał podważać własne reguły sensowności, ponieważ krytykując hipostazy, mówił o tym, o czym nie powinien. Kotarbiński, choć odpierał ten zarzut, twierdząc, że mówi o nich w sensie wtórnym, to jednak uznał go za na tyle poważny, że sugerował, aby potraktować jego reizm jako zestaw zaleceń semantycznych — przede wszystkim unikania nazw pozornych ${ }^{17}$. Jednak, jak wcześniej zaznaczyłam, Kotarbiński nigdy nie zrezygnował z tezy reizmu ontologicznego, zgodnie z którą byt to nic innego jak rzecz. Podobne przekonanie, na co rzadko zwraca się uwage, jest obecne w filozofii Heideggera.

10 T. Kotarbiński, Fazy rozwojowe konkretyzmu, s. 229-231; J. Woleński, Kotarbiński, s. 41.

11 A. Leszczyński, O materializmie filozoficznym T. Kotarbińskiego, „Studia Filozoficzne” 1 (1985), s. 124 .

12 T. Kotarbiński, Zasadnicze myśli pansomatyzmu, s. 290; E. Grodziński, Tadeusza Kotarbińskiego..., s. 87 .

${ }^{13}$ T. Kotarbiński, O różnych znaczeniach słowa „materializm”, [w:] idem, Wybór pism, t. 2, Warszawa 1958, s. 88; E. Grodziński, Tadeusza Kotarbińskiego..., s. 88.

14 T. Kotarbiński, Elementy teorii poznania, logiki formalnej i metodologii nauk, Wrocław-Warszawa-Kraków 1961, s. 341-342; R. Urbaniak, Abstrakcja bez bytów abstrakcyjnych, „Przegląd Filozoficzny" 3 (2012), s. 15.

${ }^{15}$ T. Kotarbiński, Humanistyka bez hipostaz. Próba eliminacji hipostaz ze świata pojęć nauk humanistycznych, [w:] idem, Wybór pism, t. 2, Warszawa 1958, s. 161-182.

16 J. Woleński, Kotarbiński, s. 54-58.

17 Ibidem, s. 58. 


\section{Śledź}

Zanim przyjrzymy się bliżej reistycznym wątkom filozofii autora Dróg lasu, warto zaznaczyć, co na pewno łączy Kotarbińskiego i Heideggera. Mianowicie, obaj sa „filozoficznymi wnukami” Franza Brentana. Tadeusz Kotarbiński jest nim jako student Kazimierza Twardowskiego, który był uczniem Brentana. Kotarbiński jednak nie rozwijał tez Twardowskiego dotyczących intencjonalności, które można uznać za kontynuację badań autora Psychologii z empirycznego punktu widzenia. Tym niemniej można dostrzec znaczące podobieństwo między metafizyką Kotarbińskiego a myślą Brentana. Zwrócił uwagę na nie Twardowski, twierdząc, że Brentana można również uznać za reistę. Kotarbiński także widział istotne w tym względzie podobieństwo, ale równocześnie podkreślał, że stanowisko Brentana to reizm dualistyczny, dopuszczający kartezjańską dwoistość res extensae i res cogitantes, a więc zakładający istnienie ciał i dusz jako odrębnych bytów ${ }^{18}$.

Heideggera można z kolei postrzegać jako należącego do tradycji Brentanowskich badań nad intencjonalnością z racji tego, że był podopiecznym Edmunda Husserla, który kształcił się pod kierunkiem Brentana (w podobnym okresie co Kazimierz Twardowski). Warto jednak zaznaczyć, że to nie Brentano-prekursor fenomenologii Husserla zaintrygował Heideggera, lecz Brentano-badacz Arystotelesa ${ }^{19}$. Jego książka O różnorakim znaczeniu bytu u Arystotelesa, jak relacjonuje sam Heidegger, była dla niego „pierwszą i chwiejną próbą wniknięcia w filozofię"20. W dalszym kształtowaniu się ontologii Heideggera nie ma jednak bliższego związku z filozofią Brentana ${ }^{21}$.

Fakt, że bezpośredni nauczyciele Kotarbińskiego i Heidegger byli uczniami Brentana, to jednak tylko zewnętrzne podobieństwo między nimi, podobnie jak to, że Heidegger (1889-1976) i Kotarbiński (1886-1981) rozwijali swoje stanowiska w zbliżonym okresie, od lat dwudziestych do późnych lat pięćdziesiątych XX wieku. Właściwe podobieństwo między nimi polega na skłonności do uznawania, że byt to w zasadzie rzecz, oraz niechęci wobec hipostaz, co postaram się wykazać.

Oczywiście należy w tym miejscu zaznaczyć, że nie sposób mówić o zależności między tymi dwoma filozofami. Heidegger prawdopodobnie nigdy nie słyszał o Kotarbińskim. Z kolei Kotarbiński prawdopodobnie zetknął się z nazwiskiem Heideggera, ale raczej nie darzył jego filozofii szczególną estymą. Co więcej, choć nigdzie wprost Kotarbiński tego nie stwierdził, można przypuszczać, że to właśnie

18 T. Kotarbiński, Uwagi na temat reizmu, s. 10-11; T. Kotarbiński, Fazy rozwojowe konkretyzmu, s. $231-232$.

19 S.J. McGrath, The Early Heidegger and Medieval Philosophy: Phenomenology for the Godforsaken, Washington 2014, s. 27.

${ }^{20}$ Heidegger komentuje to, mówiąc: „W dość nieokreślony sposób poruszyła mnie myśl: skoro o bycie mówi się w różnych znaczeniach, które jest przewodnim znaczeniem podstawowym? Co to znaczy bycie?" — idem, Moja droga do fenomenologii, tłum. C. Wodziński, [w:] idem, Ku rzeczy myślenia, tłum. K. Michalski, J. Mizera, C. Wodziński, Warszawa 1999, s. 101.

${ }^{21}$ S. Kamińska, Wybrane aspekty wielorakiego znaczenia bytu i intencjonalności w ujęciu Franza Brentana i Martina Heideggera, „Argument” 2 (2013), s. 253-271; D.F. Krell, On the manifold of meaning of Aletheia: Aristotle, Brentano, Heidegger, „Research in Phenomenology” 5 (1975), s. 77-94; zob. J.D. Caputo, Heidegger and Aquinas: An Essay on Overcoming Metaphysics, New York 1982, s. 57-58. 
filozofia Heideggera była dla niego przykładem ciemnych głębin z jego słynnego epigramu o śledziu ${ }^{22}$.

\section{Bycie takie jak nic}

Przed przystąpieniem do rekonstrukcji ontyki Heideggera w kontekście jej reistycznego odczytania warto najpierw zwrócić uwagę na pewien aspekt jego ontologii. Prawdopodobnie niewiele jest bardziej obcych perspektywie reizmu semantycznego koncepcji filozoficznych niż Heideggerowskie ujęcie problemu bycia. Zarówno przedmiot tej analizy, jak i specyfika języka Heideggera łamią najbardziej podstawowe postulaty semantyki Kotarbińskiego. Jednak w Heideggerowskim podejściu do kwestii bycia można wskazać ważny rys, który łączy je z reizmem ontologicznym: jest to niechęć do substancjalizowania bycia, czynienia z niego quasi-bytu.

Punktem wyjścia ontologii Heideggera jest krytyka dominującego w metafizyce rozumienia bycia jako obecności bytu. Co więcej, to ujęcie równocześnie hipostazuje bycie w rodzaj bytu — zgodnie z nim bycie to czysta obecność (Vorhandenheit), współczesność (Gegenwart) bądź uobecnienie (Anwesenheit) ${ }^{23}$.

Heidegger tymczasem zakłada, że ,» bycie « nie jest czymś takim jak byt" ${ }^{24}$. Bycie, po pierwsze, nie stanowi bytu, po drugie, nie będąc bytem, nie jest tak jak byt. Bycie ,jest" więc inne i inaczej niż byt ${ }^{25}$. Odpowiednie ujęcie różnicy między byciem a bytem wymaga jednak uwzględnienia ich nierozłączności, która polega na tym, że bycie stanowi źródłowe określenie bytu. W Byciu i czasie Heidegger pisze: „Tym, o co pyta pytanie, które mamy opracować, jest bycie, to, co określa byt jako byt [...]”. I dalej: „Skoro bycie stanowi to, o co pytanie pyta, a »bycie« znaczy »bycie bytu «, więc tym, czego zapytywanie dotyczy w pytaniu o bycie, okazuje się sam byt. Pytamy o niego niejako ze względu na jego bycie" ${ }^{26}$.

Powinniśmy więc pamiętać, że Heidegger nie planuje dokonać eliminacji rozważań o bycie z metafizyki, lecz pokazać, że byt jest zrozumiały tylko w relacji z byciem $^{27}$. Taką perspektywę rozważania problemu bytu należy odróżnić od podejścia „ontycznego", które jest zasadniczo zorientowane na substancję i budowę bytu. Pytanie dotyczące bycia bytu, jego rozumienia, Heidegger określa jako „ontologiczne” i uznaje za pierwotne względem wymiaru ontycznego ${ }^{28}$. Bycie nie jest, lecz — jak pokazywał na przestrzeni swojej drogi myślowej Heidegger — dzieje się, wydarza, przy-swaja, istoczy. Tak też byt rozumiany ontologicznie nigdy nie jawi się jako obecny, ale dziejący się, wydarzający, istoczący w (swym) byciu.

22 „Do jasnych dążąc głębin — nie mógł trafić w sedno / Śledź pewien, obdarzony naturą wybredną. Dokądkolwiek wędrował, zawsze nadaremno: Tu jasno, ale płytko — tam głębia, lecz ciemno" — http:// pauza.krakow.pl/307_4_2015.pdf (dostęp: 15.05.2018).

23 Zob. M. Heidegger, Bycie i czas, tłum. B. Baran, Warszawa 2004, s. 33.

24 Ibidem, s. 4.

${ }^{25}$ Zob. ibidem, s. 48; zob. C. Wodziński, Heidegger i problem zła, Gdańsk 2007, s. 305-306.

${ }^{26}$ M. Heidegger, Bycie $i$ czas, s. 8-9.

${ }^{27}$ Zob. J. Mizera, W strone filozofii niemetafizycznej. Martina Heidegger droga do innego myślenia, Kraków 2006, s. 29; M. Inwood, Heidegger's Dictionary, Oxford-Malden 2000, s. 150.

${ }^{28}$ Zob. M. Heidegger, Bycie i czas, s. 16-17. 
Chcąc jednak jednoznacznie odciąc się od tendencji rządzącej historią metafizyki do redukowania bycia do (cechy) bytu, Heidegger wprowadził w późniejszych pracach pojęcie Bycia $(\text { Seyn })^{29}$. Staroniemiecka pisownia Seyn miała być znakiem ostatecznego zerwania z rozumowaniem klasycznej metafizyki i odrzuceniem jej kategorii. Archaiczny zapis Seyn miał podkreślać pogłębienie radykalizmu filozofa w myśleniu bycia. Seyn to bowiem bycie samo, które jest różne od bycia bytu, czyli Sein. W Przyczynkach do filozofii czytamy: „Bycie (Sein) i Bycie (Seyn) sa tym sa-

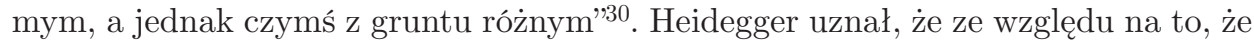
Sein jest tak silnie obciążone bagażem tradycji, musi wprowadzić inne pojęcie, aby wyrazić swoją koncepcję bycia. Heidegger jednak w dalszym ciągu posługiwał się tymi dwoma terminami, rezerwując Seyn raczej dla podkreślenia odmienności bycia od bytu. Tym niemniej bycie i byt dalej pozostały w filozofii Heideggera ściśle z sobą złacczone. W Posłowiu do „Czym jest metafizyka?” czytamy, że „nie istoczy się ono [bycie w sensie Seyn] nigdy bez bytu i że nigdy nie ma bytu bez bycia"31.

Innym sposobem pokazania przez Heideggera, że bycie to nie żaden rodzaj bytu, jest uznanie bycia za (takie jak) Nic: „Musimy zdecydować się na ustanowienie bycia jako Niczego (Nichts), skoro Nic oznacza nie-byt (Nicht-seiende)"32. Warto zauważyć, że termin „nic” lepiej uwidacznia odrębność i zarazem równość wobec bytu niż „nie-byt”, niosacy w sobie jakąś wtórność w stosunku do bytu ${ }^{33}$. Pozwala zarazem uniknacć hipostazowania bycia, czyli nadania mu jakiejkolwiek substancjalności ${ }^{34}$. Z tego też powodu słowo „nic” jest trafniejsze niż „nicość”, ponieważ mocniej odrzuca złudne intencje, sugerujące, że kryje się za nim forma quasi-bytu, jak dzieje się nieraz w wypadku nicości ${ }^{35}$.

Jakkolwiek więc Heideggerowskie rozważania o Niczym dla reisty semantycznego są pozbawione sensu (w tym przypadku Kotarbiński i Rudolf Carnap, jako krytyk Heideggera, mogliby uścisnąć sobie dłonie ${ }^{36}$ ), to z punktu widzenia reizmu ontologicznego i jego niechęci do hipostaz są one trafne. Podobnie można byłoby ocenić pojęcie „bytości” (Seiendheit) komplementarne wobec ujęcia bycia jako Niczego. Ma ono dla Heideggera pejoratywne znaczenie. Bytość to bycie traktowane jako to, co stale obecne i ogólne w bytach. Bycie jako bytość utożsamiano

${ }^{29} \mathrm{~W}$ polskich przekładach ten termin pisany jest majuskułą w celu oddania różnicy graficznej w stosunku do bycia (Sein). Nie ma to więc w żadnym wypadku sugerować, jakoby „Bycie” stanowiło jakiegokolwiek rodzaju absolut; zob. J. Mizera, W strone filozofii.., s. 14.

${ }^{30}$ M. Heidegger, Przyczynki do filozofii. Z wydarzania, tłum. B. Baran, J. Mizera, Kraków 1996, s. 163; zob. C. Wodziński, Heidegger..., s. 351.

31 M. Heidegger, „Czym jest metafizyka?”. Posłowie, tłum. K. Wolicki, [w:] idem, Znaki drogi, tłum. S. Blandzi et al., Warszawa 1999, s. 266.

32 Ibidem, s. 268.

${ }^{33}$ Por. I.S. Fiut, Negacja i niebyt: ujęcie systemowe G.W.F. Hegla i Martina Heideggera, Kraków 1997, s. 41.

${ }^{34}$ Zob. E. Borowska, Ewolucja metafizyki europejskiej w interpretacji późnego Heideggera, Warszawa 2008, s. 133 .

35 Zob. B. Skarga, Tercet metafizyczny, Kraków 2009, s. 222; M. Hoły-Łuczaj, Bycie, czyli Nic. Przyczynek do lektury Heideggera, Kraków 2012, s. 9-10.

${ }^{36}$ Choć, jak zauważa Jan Woleński, reizm ontologiczny stanowi typowy pogląd metafizyczny w rozumieniu neopozytywistów i jako taki jest wedle nich bezsensowny; zob. J. Woleński, Kotarbiński, s. 70. 
z zespołem właściwości (lub jedną wybraną właściwością), który determinował konstytucję bytu jako takiego ${ }^{37}$. Bycie rozumiane jako bytość było więc także (abstrakcyjną) hipostazą.

Sprzeciw Heideggera wobec prób czynienia z bycia bytu — hipostazowania go - był podyktowany dążeniem do wydobycia bycia z zapomnienia i odkrycia jego sensu. Jest to znacząco inna motywacja niż ta kierująca Kotarbińskim, który krytykował różne hipostazy, aby pokazać, że jedyny rzeczywisty rodzaj bytów to rzeczy. Co jednak powinno zwrócić naszą uwagę, u Heideggera również obecna jest zastanawiająca skłonność, aby za byt sensu stricto uznawać rzeczy-konkrety.

\section{Konkrety}

Ogrom spuścizny Heideggera, mierzony choćby liczbą tomów opublikowanych w serii dzieł zebranych, zmusza badaczy do wyboru określonych prac, które moga poddać analizie. Nie inaczej jest w wypadku niniejszej interpretacji, która obejmuje: Bycie i czas, Die Grundbegriffe der Metaphysik. Welt-Endlichkeit-Einsamkeit, Logik als die Frage nach dem Wesen der Sprache, Pytanie o rzecz, Źródło dzieła sztuki, Przyczynki do filozofii, O istocie i pojęciu physis oraz Rzecz. Wybierając te pozycje, chcę wskazać kierunek zmian, jakie zaszły w Heideggerowskiej ontyce $\mathrm{w}$ rezultacie zwrotu.

Istnieją dwie, komplementarne względem siebie wykładnie zwrotu (Kehre). Zgodnie z pierwszą, sugerowaną przez Heideggera, zwrot jest odwróceniem antropocentrycznej orientacji filozofii w stosunku do bycia, co rozpoczyna nową epokę w jej dziejach. Druga wykładnia również traktuje zwrot jako odrzucenie przekonania o zwierzchności człowieka nad byciem, ale dostrzega je wyłącznie w późniejszej filozofii samego Heideggera. Wydaje się jednak, że najtrafniej jest łączyć obie te interpretacje, widzac $\mathrm{w}$ transformacji filozofii Heideggera dążenie do ustanowienia filozoficznego fundamentu dla innego rozumienia bycia ${ }^{38}$.

Przypomnijmy, że u Heideggera człowiek to przykładowy byt ${ }^{39}$, który ma jednak pierwszeństwo w opracowywaniu pytania o bycie ${ }^{40}$. Wynika ono ze struktury ontologicznej człowieka, którą wyraża pojęcie jest-estwa (Dasein), i polega na tym, że człowiek „w jakiś sposób i do pewnego stopnia wyraźnie rozumie siebie w swoim byciu. Swoiste dla tego bytu jest to, że wraz z jego byciem i poprzez nie bycie to zostaje mu otwarte" ${ }^{41}$. Ta bezpośredniość kontaktu z (własnym) byciem jest tym, co pozwala mu postrzegać inne byty w (ich) byciu ${ }^{42}$.

\footnotetext{
37 Zob. K. Michalski, Słownik pojęć filozofii Martina Heideggera, [w:] idem, Zrozumieć przemijanie, Warszawa 2011, s. 235.

38 I. Thomson, Heidegger on Ontotheology: Politics and Technology of Education, Cambridge 2005, s. 179, 191; J. Mizera, W strone filozofii..., s. 9-11.

${ }^{39}$ Zob. M. Heidegger, Bycie i czas, s. 9. B. Baran tłumaczy tu exemplarische jako ,egzemplaryczny".

40 Zob. ibidem, s. 9.

41 Ibidem, s. 16.

42 Zob. B. Baran, Saga Heideggera, Kraków 1992, s. 45-46; K. Michalski, Heidegger i filozofia wspótczesna, Warszawa 1976, s. 77-81.
} 
Według Heideggera tylko człowiekowi przysługuje ten szczególny rodzaj relacji z byciem, jakim jest jego rozumienie, dlatego również tylko on stanowi jestestwo. Nie znaczy to jednak, że bycie jest właściwe jedynie człowiekowi, co Heidegger dookreśla w rezultacie zwrotu. Dla poprawnego uchwycenia charakteru zwrotu u Heideggera powinno się bowiem mieć na uwadze to, że nie tyle jest on odrzuceniem dawnych poglądów Heideggera i przyjęciem nowych, ile innym rozłożeniem w nich akcentów. To przesunięcie akcentów znacząco jednak zmieniło wymowę najważniejszych kwestii. Najlepiej widać to w wypadku zagadnienia prawdy. We wczesnych pracach Heideggera prawda bycia opierała się na „,autentycznej” egzystencji jestestwa. Natomiast w następstwie zwrotu to otwartość samego bycia staje się istotą prawdy, która stanowi podstawę swoistości jestestwa. Mowa o tym po raz pierwszy w wykładzie O istocie prawdy (1930), który jest powszechnie uważany za przełom w filozofii Heideggera ${ }^{43}$. Konsekwencją zapoczątkowanej tam przemiany jest wiodacce dla zwrotu przekonanie, że to nie bycie (Sein) ma być myślane od strony Dasein, ale Dasein od strony bycia ${ }^{44}$.

Wykład $O$ istocie prawdy jest jednak tak znaczacy w dorobku Heideggera nie tylko dlatego, że po raz pierwszy inaczej przedstawia zależność bycia i jestestwa, lecz także dlatego że dokonuje rewaloryzacji statusu skrytości ${ }^{45}$. Choć już Bycie $i$ czas pokazuje, że prawda bycia bytu jako a-letheia pierwotnie skrywa się, to w tej pracy Heidegger koncentruje się na doniosłości jej odkrywania. Natomiast odczyt ze Znaków drogi podkreśla wagę skrytości bycia: „skrytość bytu w całości, właściwa nie-prawda jest starsza niż każda jawność tego czy owego bytu”46. „Byt w całości" zdaje się odnosić do bytu jako bytu, a więc bytu w jego byciu. To właśnie bycie skrywa się. To ,skrycie skrytego" Heidegger nazywa tajemnicą ${ }^{47}$. Tak też tajemnica jest tym, czego się strzeże i chroni ${ }^{48}$. Z drugiej strony, tajemnica odmawiajacc siebie, niknie w pozorach zapomnienia ${ }^{49}$. Tajemnica ze swej natury jest bowiem tym, co nieznane, dlatego też to, czego dotyczy, jest w oczywisty sposób pomijane. Wyeksponowanie źródłowego charakteru skrytości ukazuje tym samym zapomnienie bycia w nowej perspektywie. Bycie niejako samo popada w zapomnienie, skrywając się. Zawsze musi zostać od-pomniane, czyli od-kryte: skrywanie to podstawowy rys bycia ${ }^{50}$. To właśnie posłanie człowieka: odkrywać bycie. Nie tylko własne, ale tė̇ innych bytów. Byty inne niż człowiek, co Heidegger dookreśli po zwrocie (który dopełnił się w okolicach lat 1935-1936), są w skrytości. Jakie to jednak właściwie byty?

W Byciu i czasie (1927) pojawiają się zasadniczo dwa rodzaje bytów: człowiek jako jestestwo oraz byty wewnątrzświatowe. Różni je stosunek do bycia.

${ }^{43}$ W.J. Richardson, Heidegger, Through Phenomenology to Thought, New York 2003, s. 211; B. Baran, Saga Heideggera, s. 69-73.

44 Zob. M. Heidegger, Przyczynki do filozofii.., s. 279.

45 B. Baran, Saga Heideggera, s. 74.

${ }^{46}$ Zob. M. Heidegger, O istocie prawdy, tłum. M. Filek, [w:] idem, Znaki drogi, s. 170.

47 Zob. ibidem.

48 Zob. B. Baran, Saga Heideggera, s. 74.

49 Zob. M. Heidegger, O istocie prawdy, s. 171.

${ }^{50}$ Ibidem, s. 176. 
Człowiek rozumie bycie i może je odkrywać, natomiast byty wewnątrzświatowe nie mogą odnieść się do (swojego) bycia ${ }^{51}$. Określenie „wewnątrzświatowe” nie jest synonimem słowa „ziemskie”, lecz pochodzi od nazwy struktury ontologicznej, jaką jest Heideggerowski ,świat”. Najkrócej można powiedzieć, że jest to horyzont sensu - horyzont rozumienia i odkrywania bycia. Bycie $i$ czas opisuje go poprzez charakter narzędzia. Narzędzie, jak stara się pokazać Heidegger, zawsze jest powiązane z określoną funkcją (przedmioty służące do pisania) oraz działa tylko wraz z innym rzeczami (długopisem piszemy na kartce, która leży na biurku, przy którym siedzimy na krześle itd.). Całokształt tych odniesień tworzy właśnie strukturę znaczeniowości, w której odkrywa się sens bycia ${ }^{52}$.

Do bytów wewnątrzświatowych Heidegger wydaje się zaliczać rzeczy użytkowe oraz przyrodę, ożywioną oraz nieożywioną, przypisując im różne sposoby bycia (bycie-poręcznym, bycie-żywym, bycie-obecnym) ${ }^{53}$. Obok analiz jestestwa to im poświęca najwięcej miejsca. Ten typ bytów można zaś zaklasyfikować jako konkrety — jednostkowe byty o określonej materialnej tożsamości. Oczywiście Heidegger nie opisuje ich substancji, tak jak człowieka nie ujmuje poprzez złożenie ducha i ciała (do których to zagadnień wrócimy w dalszym ciągu analizy). Według autora Bycia $i$ czasu byłaby to perspektywa ontyczna, która przesłania problem bycia. Dlatego też w opisie człowieka jako jestestwa koncentruje się na aktach rozumienia bycia. Istotne dla nas jest to, że Heidegger nie traktuje ich jako bytów, ale jako swoisty dla człowieka sposób bycia. Bycie człowiekiem dzieje się, później powiedzielibyśmy: „wydarza się", w aktach rozumienia bycia.

Podobnie Heidegger nie chce substancjalizować przestrzeni. Pisze, że współcześnie interpretacja bycia przestrzeni sprawia tyle problemów ze względu na brak przejrzystości w kwestii bycia w ogóle ${ }^{54}$. Sam Heidegger skłania się do tego, aby uznać, że przestrzeń to swoista relacyjność, jaką ustanawia wokół siebie byt. Trafnie to ujmuje Hanna Buczyńska-Garewicz, pisząc, że w Byciu i czasie ,to nie rzecz jest w przestrzeni, nie rzecz jest określana przez przestrzeń, lecz przeciwnie, rzecz staje się początkiem przestrzeni, to z niej przestrzeń dopiero się wyłania" ${ }^{\prime 55}$.

Heidegger również nie jest skłonny do tego, aby uznawać za byt przedmioty abstrakcyjne w rodzaju znaków. W Byciu i czasie odróżnia znaki od śladów, pozostałości, zabytków, świadectw, koncentrując się na narzędziowym charakterze przedmiotów w rodzaju znaków przydrożnych, kamieni granicznych, sygnałów (na przykład burzowego), flag, znaków żałoby ${ }^{56}$. Heidegger argumentuje na przykładzie samochodowego kierunkowskazu, że w ich wypadku odniesienie to nie tyle słu-

${ }^{51}$ Por. M. Heidegger, Podstawowe problemy fenomenologii, tłum. B. Baran, Warszawa 2009, s. 190: „rozumienie bycia przysługujące intencjonalności obejmuje zarówno bycie jestestwa, jak i bycie wewnątrzświatowego bytu niebędącego miary jestestwa”.

52 M. Heidegger, Bycie i czas, s. 81-112.

${ }^{53}$ Zob. M. Heidegger, Podstawowe problemy fenomenologii, s. 190.

${ }^{54}$ M. Heidegger, Bycie $i$ czas, s. 144.

${ }^{55}$ H. Buczyńska-Garewicz, Miejsca, strony, okolice. Przyczynek do fenomenologii przestrzeni, Kraków 2006, s. 103.

${ }^{56}$ M. Heidegger, Bycie i czas, s. 99-100. 
żebność, ile pokazywanie ${ }^{57}$. Co ważne, Heidegger w tym wypadku podkreśla również, że abstrakcja, jaką jest odniesienie znaku, to nie żaden byt: „,[odniesienie] nie jest ontycznym określeniem czegoś poręcznego, bo konstytuuje samą poręczność"58.

Kolejną ważna pozycją w rekonstrukcji Heideggerowskiej ontyki są Die Grundbegriffe der Metaphysik. Welt-Endlichkeit-Einsamkeit. W tym wykładzie kursowym wygłoszonym w roku akademickim 1929/1930 jednym z głównych problemów jest również podział bytów ze względu na ich sposób odnoszenia się do świata rozumianego jako struktura jawności bycia. Heidegger koncentruje się tu na kształtującym-świat (weltbildend) człowieku, ubogim w świat (weltarm) zwierzęciu oraz bezświatowym (weltlos) kamieniu ${ }^{59}$. W Die Grundbegriffe der Metaphysik pojawiają się jednak jeszcze inne byty. Są to narzędzia, przyrządy i maszyny (które Heidegger odróżnia ze względu na sposób ich funkcjonowania) oraz obiekty materialne (jako różne od artefaktów technicznych), które w jednej klasyfikacji Heidegger zdaje się utożsamiać z nieożywioną naturą ${ }^{60}, \mathrm{w}$ innej zaś oddziela te dwie grupy, nie podając jednak żadnych przykładów dla tej ostatniej grupy ${ }^{61}$. Ponadto w tej drugiej klasyfikacji rodzajów bytu Heidegger umieszcza także historię, produkty ludzkiej pracy oraz kulturę ${ }^{62}$. Komentując jednak kilka zdań dalej różnorodność bytów, mówi tylko o obecności lądu i morza, gór i lasów, innych ludzi oraz tworów ich pracy, jeszcze dalej zaś na tej samej stronie, charakteryzując z kolei jedność doświadczenia świata, mówi o wsiadaniu do tramwaju, wołaniu psa, rozmowach z innymi ludźmi i spoglądaniu w gwiazdy ${ }^{63}$. Pod koniec wykładów mówi z kolei o innych ludziach, zwierzętach, roślinach, materialnych rzeczach i dziełach sztuki ${ }^{64}$.

W Die Grundbegriffe der Metaphysik mamy więc ponownie do czynienia głównie z bytami, które można zaliczyć do konkretów. Historia i kultura choć są wymienione, nie doczekały się pogłębionej analizy sposobów ich bycia.

Nieco inaczej przedstawia się sprawa w Logik als die Frage nach dem Wesen der Sprache. W tym wykładzie wygłoszonym w semestrze letnim 1934 roku Heidegger przyjmuje następujące tezy: ludzie są na sposób jesteswa; zwierzęta i rośliny też są, ale jako żyjacce; liczby i figury geometryczne także są, ale jako zwykły zasób (bloße Bestände); ziemia i kamień również są, ale jako jedynie obecne (bloß vorhanden $)^{65}$.

W tej klasyfikacji zwraca uwagę wyodrębnienie sposobu bycia bytów matematycznych - liczb i figur geometrycznych. Jest to właściwie wyjątek w obrębie prac Heideggera. Wcześniej nie formułował sądów dotyczących ich statusu ontologicznego. Później zaś pojęcie „zasobu” (Bestand), którym tu charakteryzuje bycie figur i liczb, stanie się pejoratywnym określeniem sposobu pojmowania bytu przez

57 Ibidem, s. 101.

58 Ibidem, s. 106.

${ }^{59}$ M. Heidegger, Die Grundbegriffe der Metaphysik. Welt-Endlichkeit-Einsamkeit, Frankfurt am Main 1983, s. 261.

60 Ibidem, s. 312.

61 Ibidem, s. 398.

62 Ibidem.

63 Ibidem, s. 398-399.

${ }^{64}$ Ibidem, s. 514.

${ }^{65}$ M. Heidegger, Logik als die Frage nach dem Wesen der Sprache, Frankfurt am Main 1998, s. 135. 
nowoczesną technikę. Ponadto Heidegger nie będzie zajmował się już statusem bytów matematycznych, ale podejmie się krytyki matematycznego poglądu na świat jako właściwego nowożytności ${ }^{66}$.

Heidegger przedstawia ją już w Pytaniu o rzecz (1935-1936), przyjmującym optykę właściwą dla zwrotu. W tym momencie najważniejsze jest to, że Heidegger, zgodnie z tytułem wykładu, próbuje określić, czym jest rzecz. Zastanawiające jest to, że nie pyta o to, czym jest byt, tylko koncentruje się na rzeczach. Być może chciał uczynić swoje rozważania bardziej przystępnymi, skupiajacc się na określonym typie bytów zgodnie z przekonaniem, że „od dawna rzeczy w swej rzeczowości uchodziły za miarodajne byty", co Heidegger stwierdził w wygłoszonym w podobnym czasie odczycie Źródło dzieła sztuki ${ }^{67}$. Takie uściślenie wydaje się jednak mieć inny, bardziej znaczący powód.

W Pytaniu o rzecz Heidegger rozpoczyna swój tok wywodu od potocznego rozumienia rzeczy:

Najpierw: O czym myślimy, kiedy mówimy „rzecz”? Mamy na myśli kawałek drewna, jakiś kamień; nóż, zegar; jakąś piłkę, oszczep; jakąś śrubę lub jakiś drut; lecz także halę dworcową nazywamy „ogromną rzeczą", podobnie potężną sosnę. Mówimy o wielu rzeczach, które przywołują na myśl lato: trawy i zioła, motyle i chrabąszcze; tę tam rzecz - mianowicie obraz — także nazywamy rzeczą, a rzeźbiarz ma w swojej pracowni rozmaite gotowe i niegotowe rzeczy.

Natomiast wahamy się już nazwać rzeczą liczbę 5 . Liczby nie można dotknąć, zobaczyć ani usłyszeć. Podobnie zdanie „Pogoda jest kiepska” nie uchodzi za rzecz, tak samo jak pojedyncze słowo „dom”. Odróżniamy bowiem rzecz „dom” od słowa, które nazywa tę rzecz. Również stanowisk ani przekonań, które przyjmujemy lub od których odstępujemy, nie bierzemy za rzeczy ${ }^{68}$.

W związku z tym Heidegger uznaje, że istnieje węższe i szersze znaczenia słowa „rzecz”. „Rzecz” w węższym sensie oznacza to, co uchwytne i widoczne (kamień, kawałek drewna, obcęgi, róża, sosna, osa), w szerszym zaś oznacza każdą sprawę, coś, co jest tak lub inaczej załatwiane, zaszłości, zdarzenia, przekonania, czyny, plany ${ }^{69}$.

Heidegger podejmując się próby uchwycenia rzeczowości rzeczy, decyduje się trzymać węższego znaczenia, przyjmując, że „pytanie o rzecz, także wówczas, gdy jest ono rozumiane w szerszym i najszerszym sensie, zwykle odnosi się do węższego obszaru i z niego wychodzi”70. Decyzja o tym, aby uwzględniać to, co najbliższe i uchwytne, próbując odpowiedzieć, czym jest rzecz jako rzecz, faktycznie była niejako z góry podyktowana tym, jak Heidegger postrzegał rzecz jako taką. Heidegger przyjmuje bowiem, że:

Rzeczy są jednostkowe. [...] Kamień jest czymś w pełni określonym, jest właśnie tym oto; jaszczurka nie jest jaszczurką w ogóle, lecz właśnie tą oto, tak samo źdźbło trawy i nóż. Nie ma rzeczy w ogóle, lecz tylko rzeczy jednostkowe, a owe jednostkowe są ponadto każdorazowo tymi oto ${ }^{71}$.

\footnotetext{
${ }^{66}$ Zob. M. Roubach, Being and Number in Heidegger's Thought, London 2008, s. 98-100.

${ }^{67}$ M. Heidegger, Źródło dzieła sztuki, tłum. J. Mizera, [w:] idem, Drogi lasu, tłum. J. Gierasimiuk et al., Warszawa 1997, s. 11.

${ }^{68}$ M. Heidegger, Pytanie o rzecz. Przyczynek do Kantowskiej nauki o zasadach transcendentalnych, tłum. J. Mizera, Warszawa 2001, s. 11-12.

69 Ibidem, s. 12.

70 Ibidem, s. 14.

71 Ibidem, s. 20.
} 
Czy liczba 5 mieściłaby się w tej definicji? Czy liczba 5 mogłaby ukazać się jako jednostkowa i każdorazowa? Trudno to sobie wyobrazić. Na czym polega ta każdorazowość, spróbuję odpowiedzieć za chwilę. Teraz warto zwrócić uwagę na to, że w Pytaniu o rzecz nie ma podziału rzeczy na te, które są sztuczne (zrobione przez człowieka), naturalne, ożywione i nieożywione — Heidegger zalicza wszystkie jednostkowe, materialne byty do kategorii rzeczy.

Podobnie jest w odczycie Rzecz (1950). Heidegger ponownie pyta tu o istotę rzeczy, lecz teraz odnosi ją do kontekstu czwórni, czyli koncepcji, która na nowo ujmuje dzianie się jawności i skrytości bycia oraz miejsce w jej wydarzaniu się człowieka jako przeciwstawionego bogom. Tym niemniej zbiór rzeczy dalej pokrywa się tu ze zbiorem konkretów, bez dalszych podziałów:

[...] dzban i ława, ścieżka i pług. Ale na swój sposób rzeczami są także drzewo i staw, strumień i góra. Rzeczami, w każdej chwili na swój sposób rzeczącymi, są czapla i sarna, koń i buhaj. Rzeczami, w każdej chwili na swój sposób rzeczącymi, są lustro i klamra, książka i obraz, korona i krzyż ${ }^{72}$.

Na podstawie powyższego przeglądu prac Heideggera widać zatem, że w rozważaniach autora Znaków drogi najczęściej występują konkretne indywidua, czyli jednostkowe przedmioty o określonej fizycznej tożsamości. Właściwie w ogóle nie pojawiają się byty abstrakcyjne. Staje się to coraz bardziej zauważalne zwłaszcza w późniejszym okresie jego filozofii ${ }^{73}$. Podstawowe pytanie brzmi: dlaczego?

\section{Przyswajanie, czyli bycie-tym-oto}

Prace rekonstruujacce kształtowanie się pojęcia rzeczy w filozofii Heideggera wskazują na zmianę, jaką przyniósł w tej kwestii zwrot. Badacze podkreślają, że w jego rezultacie rzeczy zyskują na autonomiczności wobec ludzkiej aktywności ${ }^{74}$. O ile wcześniej mogło się wydawać, że w filozofii Heideggera rzeczy są niejako efektem ludzkiej konceptualizacji, która nadawała im sens, o tyle po zwrocie autor Przyczynków podkreśla, że człowiek odsłania sens (bycia) rzeczy, a nie go kreuje. Chęć odcięcia się od „subiektywistycznej” wykładni bycia wydaje się stanowić równocześnie powód, dla którego to właśnie rzeczy pojawiają się głównie w późniejszych pracach Heideggera, a nie byty abstrakcyjne jako nierozerwalnie połaczone ze sferą inteligibilną. Jakkolwiek Heidegger także po zwrocie kładzie nacisk na to, że bez

${ }^{72}$ M. Heidegger, Rzecz, [w:] idem, Odczyty i wyktady, tłum. J. Mizera, Kraków 2002, s. 161. Warto podkreślić, że to ujęcie nie prowadzi do unifikacji tych bytów. Heidegger kładzie nacisk na to, że „każda rzecz jest rzeczą na swój sposób" - ibidem.

${ }^{73}$ M. Kwietniewska, Res. Studium transformacji pojęcia rzeczy od Hegla do dekonstrukcji filozoficznej, Łódź 2009, s. 354. Warto tu przytoczyć komentarz Emmanuela Levinasa, który stwierdził, że „filozofia późnego Heideggera staje się wstydliwym materializmem. Uznając, że bycie objawia się między Niebem a Ziemią, w oczekiwaniu na bogów i w towarzystwie śmiertelnych, podnosi ona krajobraz, czyli martwą naturę, do rangi źródła człowieczeństwa" — zob. E. Levinas, Całość i nieskończoność. Esej o zewnętrzności, tłum. M. Kowalska, Warszawa 2002, s. 359.

${ }^{74}$ M. Kwietniewska, Res..., s. 354; W. Biemel, The development of Heidegger's concept of the thing, „Southwestern Journal of Philosophy” 3 (1980), s. 57. 
ludzkiego myślenia bycie nie może się odsłonićp ${ }^{5}$, to równocześnie zaznacza, że w żadnym wypadku nie można traktować bytów jako wytworów tego namysłu ${ }^{76}$.

Reistyczne nachylenie Heideggerowskiej ontyki zdaje się jednak wynikać jeszcze z innych założeń jego ontologii. Przede wszystkim jest to szczególne rozumienie czasowości i przestrzenności jako struktur bycia. To w nich ugruntowana jest jednostkowość czy też każdorazowość (Jediesheit), określająca ontologiczny status rzeczy jako rzeczy. Heidegger w Pytaniu o rzecz tłumaczy to, odwołując się do twierdzenia (które poświadcza nasze codzienne doświadczenie), że nie może być nigdy w tym samym miejscu i czasie dwóch rzeczy ${ }^{77}$. Heidegger zauważa tu jednak od razu, że czas i przestrzeń nie są czymś wewnętrznym dla rzeczy — w samej rzeczy nie znajdujemy ani czasu, ani przestrzeni. Czas i przestrzeń nie są jednak też całkowicie zewnętrzne wobec rzeczy, tworząc tylko pewien układ współrzędnych — nie sposób bowiem nawet pomyśleć rzeczy, nie widząc jej jako jednostkowej w określonym czasie i określonej przestrzeni. Rzecz zawsze ukazuje się nam jako „ta oto" (je dieses) w swojej czasowości i przestrzenności stanowiących struktury, w których ujawnia się bycie ${ }^{78}$. Dlatego też Heidegger mówi nie tylko o „czas-przestrzeni”, lecz nawet o „czasowaniu” i „uprzestrzennianiu”, chcąc po zwrocie trafniej wyeksplikować problem statusu czasu i przestrzeni, zajmujaccy go od wczesnych $\operatorname{prac}^{79}$. Tak też to rzecz myślana od strony bycia pozwala nam uchwycić sens czasu i przestrzeni (czasowania i uprzestrzenniania), poprzez co zwrotnie możliwe jest ujawnianie się danego bytu jako tego właśnie bytu.

Tu właśnie zdaje znajdować się jedna z ważniejszych przyczyn pomijania przez Heideggera bytów ogólnych. Byty ogólne, które ze swojej istoty miałyby być pozaczasowe i pozaprzestrzenne, nie mogą ujawniać się poprzez struktury czasowości i przestrzenności. Nie mogą być pomyślane w związku z czasem i przestrzenią, więc niejako muszac zostać wykluczone z uniwersum (ujawniania się) bycia w filozofii Heideggera. Jeśli to bycie określa byt jako byt, to trudno uznać przedmioty, takie jak kategorie, rodzaje lub obiekty matematyczne, za byt sensu stricto.

Jest jeszcze inny możliwy powód, dla którego to rzeczy — byty jednostkowe - stanowią właściwe byty dla Heideggera. Bycie to ujawnianie bytu jako takiego, jego właśnie, w jego swoistości. Ten sens ma też wydarzanie, które można przełożyć również jako przy-swajanie (er-eignen). Dlatego wydaje się, że istoczenie bycia może dziać się (wydarzać) tylko w bytach jednostkowych. Skoro bowiem bycie jest przyswojeniem sobie bytu jako tego oto w jego poszczególności, jak mogłoby się dziać w bycie ogólnym? Trudno to pomyśleć. Na gruncie filozofii Heideggera

${ }^{75} \mathrm{~W}$ trakcie seminariów w Zollikonie Heidegger podkreśla, że ze względu na to, że bycie nigdy nie jest substancjalnie obecne, ale istoczy się, u-obecnia się (an-west) przejawia się (erscheint), zawsze musi mieć ono świadka: „Nie ma istoczenia bez »dokąd« tego istoczenia” — M. Heidegger, Zollikoner Seminare: Protokolle, Gespräche, Briefe; herausgegeben von Medard Boss, Frankfurt am Main 1987, s. 223.

${ }^{76} \mathrm{~W}$ Przyczynkach czytamy, że pojawiły się „rażące dezinterpretacje, jak choćby ta, że wskutek zrozumiałości bycia Bycie (na dodatek pojmowane jeszcze jako byt) staje się »zależne« od podmiotu" - M. Heidegger, Przyczynki do filozofii.., s. 243.

77 M. Heidegger, Pytanie o rzecz, s. 21-22.

78 Ibidem, s. 23-27, 34-35.

${ }^{79}$ Ibidem, s. 35; zob. M. Heidegger, Przyczynki do filozofii..., s. 344-360. 
mamy więc do czynienia z istoczeniem się polnego maku, a nigdy z przejawianiem się w swoim byciu czerwieni jako takiej.

Jeśli w rozważaniach Heideggera pojawiają się powszechniki (uniwersalia), jak na przykład w O istocie $i$ pojęciu physis z 1939 roku, gdzie mowa o „tym, co drzewne”, Heidegger ma na myśli swoistość drzewa ujawniającą się w byciu poszczególnego drzewa $^{80}$. Autorowi Znaków drogi w tym względzie znacznie bliżej do filozofii Arystotelesa niż Platona. Widać to dobrze we wspomnianym przed chwilą wykładzie poświęconym Arystotelesowskiej Fizyce. Heidegger odnosi się w nim do odmiennego rozumienia idei przez tych dwóch filozofów. Zarzuca Platonowi wprowadzenie niewłaściwego sensu tego pojęcia. Przed nim „idea” była bowiem „tym, co widoczne, ale nie w sensie, że staje się nim dopiero dzięki widzeniu, lecz idea jest owym czymś nastręczającym widzeniu możliwość zobaczenia, oferującym widzialność, uwidaczniającym" 81 . Idea stanowiła więc według Heideggera to, co umożliwia zobaczenie, czyli była siłą ukazywania. W takim rozumieniu pozostaje ona bliska Heideggerowskiej koncepcji bycia jako przejawiania się bytu w swym najbardziej pierwotnym wymiarze (to jest tego, co będące). Natomiast Platon, który według Heideggera był

porwany istotą eidos, ujął ideę jako coś dla siebie wyistaczającego i w ten sposób wspólnego pojedynczym „bytom”, które „wystawione są na taki wygląd”; w konsekwencji to, co pojedyncze, jako wtórne wobec idei będącej bytem właściwym, zdegradowane zostało do roli niebytu ${ }^{82}$.

Platońska idea jest w ten sposób jedną z pierwszych form bytości. Do przed-Platońskiego rozumienia idei, jak sądzi Heidegger, w pewnym sensie wraca Arystoteles:

w przeciwieństwie do tego Arystoteles wymaga zrozumienia, że każdy pojedynczy byt, ten oto dom i tamto wzgórze, nie są czymś niebędącym, lecz właśnie bytem, o ile wystawiają się one na wygląd domu, wzgórza, stąd zaś dopiero stawiają się do wyistaczania ${ }^{83}$.

U Arystotelesa też mielibyśmy swojego rodzaju podwojenie: to istota gatunkowa zawarta w bytach jednostkowych określa tożsamość jednostkowego bytu. Tym niemniej, jak pokazuje Heidegger, według Arystotelesa przed nami zawsze ujawnia się pojedynczy, dany byt, który nie jest traktowany lekceważąco, jak miało to miejsce w metafizyce Platona ${ }^{84}$.

Sposób, w jaki Heidegger komentuje rozwiązania Platona i Arystotelesa, pozwala nam przyjąć, że konkretne indywiduum jest dla Heideggera kompletnym bytem, a nie namiastką jego idealnej postaci. Jednostkowa rzecz nie jest według niego jedynie niedoskonałym odbiciem swojego idealnego wzorca. Takie rozumienie bytu Heidegger uznaje nie tylko za niewłaściwe, ale też szkodliwe. Prowadzi ono bowiem do przekonania, że zawsze można zastąpić jedno konkretne indywiduum drugim, nie przywiązując do niego żadnej wagi. Taką postawę często przyjmują według Heideggera naukowcy:

\footnotetext{
${ }^{80}$ M. Heidegger, O istocie $i$ pojęciu physis, tłum. J. Sidorek, [w:] idem, Znaki drogi, s. 215-216.

81 Ibidem, s. 240.

82 Ibidem, s. $240-241$

83 Ibidem, s. 241.

${ }^{84}$ Ibidem, s. 245.
} 
Badając bowiem roślinę wargową, botanik nigdy nie zajmuje się jednostkową rośliną jako jednostkową; zawsze jest ona tylko pewnym okazem (Exemplar); dotyczy to także zwierząt, choćby niezliczonych żab i jaszczurek uśmierconych w laboratorium ${ }^{85}$.

Dla Heideggera to rzecz zasługuje przede wszystkim na miano bytu — tego, co będące. To na niej koncentruje się filozof, a nie na gatunkach, typach czy innych bytach ogólnych ${ }^{86}$.

Inny reistyczny wątek Heideggerowskiej ontyki to krytyka ujęcia rzeczy jako nośnika cech, która łączy się z niechęcią do substancjalizowania wrażeń. W Źródle dzieła sztuki czytamy:

$\mathrm{O}$ wiele bliższe od wszelkiego rodzaju wrażeń są nam rzeczy same. W domu słyszymy trzaskające drzwi, nigdy natomiast nie słyszymy wrażeń akustycznych ani samych tylko szumów ${ }^{87}$.

Heidegger jest również niechętny koncepcji obrazów wewnętrznych. Sceptycyzm wobec nich łączy się z kolei ze sprzeciwem wobec kwestionowania istnienia świata zewnętrznego, który filozof wyraża wprost już w Byciu i czasie ${ }^{88}$. W Co zwie sie myśleniem? niechęć do podważania istnienia świata zewnętrznego Heidegger oddaje poprzez serię retorycznych pytań, komentując problematyczność idei przedstawiania:

Stoimy naprzeciw drzewa [...]. Stoimy tak, jak jesteśmy, nie tylko umysłem i świadomością, naprzeciw kwitnącego drzewa, a drzewo przedstawia się nam takie, jakie jest. [...] Czy jednak drzewo znajduje się „w świadomości”, czy na łące? Czy łąka jako przeżycie tkwi w duszy, czy rozpościera się na ziemi? Czy ziemia znajduje się w umyśle? Czy to raczej my stoimy na ziemi? ${ }^{89}$

W tym miejscu warto odnieść się do zarzutu stawianego Heideggerowi, że lekceważy on biologiczne uwarunkowania ludzkiej egzystencji, zwłaszcza cielesną kondycję człowieka. Bioracc pod uwagę rozległość Heideggerowskiej spuścizny, faktycznie należy uznać, że nie poświęcił zbyt wiele miejsca tej problematyce ${ }^{90}$. Abstrahowanie od niej nie tyle jednak powinno być postrzegane jako skłonność Heideggera do traktowania człowieka jako istoty niemal anielskiej ${ }^{91}$, ile jako odejście od redukcji ontycznej. Heidegger przyjmuje, że rozpatrywanie człowieka poprzez triadę „ciało-dusza-rozum” stanowi perspektywę ontyczną. Byt w takim ujęciu nie jest określany przez bycie, ale poprzez swoją substancję i budowę. Pozostaje przez to ontologicznie nieokreślony: tradycyjna metafizyka nie wyjaśnia, co ma znaczyć, że ciało lub dusza są. Ta ich ontologiczna nieokreśloność przekłada się na ontologiczną nieokreśloność samego człowieka: nie wyjaśnia sensu jego bycia ani jego

${ }^{85}$ M. Heidegger, Pytanie o rzecz, s. 21.

${ }^{86}$ Heidegger krytykuje jednak średniowieczny nominalizm — uznający to, co jednostkowe, za najbardziej realne (obecne i pewne) — za to, iż doprowadził do tego, że to jednostkowa dusza i jednostkowy człowiek, czyli „Ja”, zostały uznane za coś najbardziej bytującego, a więc najbardziej realnego. To bowiem otworzyło drogę do powstania koncepcji ego cogito, ergo sum, czyli narodzin nowożytnego podmiotu, który z kolei utorował drogę nowoczesnej technice. Zob. M. Heidegger, Przyczynki do filozofii..., s. 200-201.

${ }^{87}$ M. Heidegger, Źródło dzieła sztuki, s. 14, zob. 12-13; por. M. Kwietniewska, Res..., s. 192.

${ }^{88}$ M. Heidegger, Bycie i czas, s. 257-262.

${ }^{89}$ M. Heidegger, Co zwie się myśleniem?, tłum. J. Mizera, Warszawa 2000, s. 27.

${ }^{90}$ Choć ekskurs w Die Grundbegriffe der Metaphysik poświęcony organizmowi jest rozbudowany i bardzo interesujaccy; zob. ibidem, s. 311-344.

${ }^{91}$ D.F. Krell, Daimon Life. Heidegger and Life-Philosophy, Bloomington 1992, s. 52. 
zdolności do rozumienia bycia jako jestestwa ${ }^{92}$. Tym niemniej Heidegger był jak najdalszy od ontologicznego dezawuowania ciała. W jego pismach można nawet zaobserwować wręcz przeciwną tendencję. Ważne są tu na przykład dwa fragmenty z wykładów o Nietzschem:

[...] być może to ciało (Leib), z tym jak ono żyje i się cieleśni, jest tym, co w nas najbardziej pewne, pewniejsze niż „dusza” i „duch”; i to może ciało, a nie dusza jest tym, o czym mówimy, że jest ,,uduchowione",93.

[...] nie jest tak, że jesteśmy wpierw ,żywi", a następnie mamy do tego jeszcze aparaturę zwaną ciałem, lecz żyjemy, będąc cieleśni (sondern wir leben, indem wir leiben $)^{94}$.

To pozytywne waloryzowanie cielesności jest także spójne z nastawieniem reistycznym, które, jak starałam się pokazać, jest silnie obecne w Heideggerowskiej ontyce.

Jednak nie bez powodu wielu badaczy filozofii Heideggera podkreśla, że nie jest ona systemem, który można poddać jednoznacznej klasyfikacji ${ }^{95}$. Heideggerowska ontyka nie jest tu wyjątkiem. W pracach Heideggera można znaleźć fragmenty, jakkolwiek nieliczne i pozbawione komentarza, w których filozof zdaje się traktować jako byty na przykład czyn, ofiarę i machinację:

[...] pozostanie pytanie o to, w jaki sposób uporządkować wszystko ożywione, „naturę" i to, co w niej nieożywione, jak narzędzie machinacja, dzieło, czyn, ofiara i ich siła prawdy $[\ldots]^{96}$.

Są rzeczy i są ludzie, są dary i ofiary, jest zwierzę i roślina, jest narzędzie i dzieło ${ }^{97}$.

Przytoczone cytaty pochodzą z Przyczynków do filozofii oraz Źródła dzieła sztuki. Machinacja to pewien sposób istoczenia bycia, właściwego postrzeganiu go przez pryzmat wykonalności, które sprzyja jego bezistociu — zakrywaniu jego sensu $^{98}$. Bycie, jego rodzaje i sposoby istoczenia — zgodnie $\mathrm{z}$ podstawowymi założeniami ontologii Heideggera — nie powinny być jednak traktowane jako jakiegokolwiek typu byty (zob. Bycie jest takie jak nic). Dlatego wydaje się, że machinacja jako sposób istoczenia bycia również nie powinna być uznana na gruncie filozofii Heideggera za byt. Z kolei czyn i ofiara zdają się raczej aktami, poprzez które ujawnia się bycie człowieka niż samodzielnymi bytami mogącymi istoczyć się w swoim byciu. Rozpoznanie ich jako bytów byłoby zatem zbędnym podwojeniem.

92 Zob. M. Heidegger, Bycie $i$ czas, s. 61.

${ }^{93}$ Ibidem, s. 560. Ta uwaga pozostaje w sprzeczności, jak się zdaje, ze stwierdzeniem z Wprowadzenia do metafizyki, zgodnie z którym to duch jest gwarantem siły i urody ciała (zob. ibidem, s. 47). Można jednak nie stawiać ich w ostrym kontraście względem siebie, pamiętając, że w wykładzie z 1935 roku „duch” wydaje się stanowić synonim bycia. Znaczyłoby to więc, że to bycie funduje właściwy status ciała. Taka zaś konstatacja przedstawia się jako zgodna z logiką filozofii Heideggera.

${ }^{94}$ M. Heidegger, Nietzsche, t. 1, tłum. A. Gniazdowski et al., Warszawa 1999, s. 112. Analogiczną

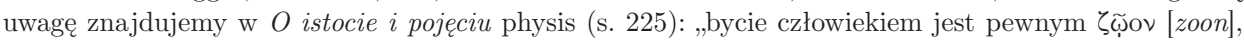
czymś żywym, co tylko żyje, o ile jest cielesne [indem es ,leibt'].

95 J. Mizera, W strone filozofii..., s. 11; A.L. Zachariasz, Tylko Bóg może nas uratować, „Sofia” 11 (2011), s. 32 .

${ }^{96}$ M. Heidegger, Przyczynki do filozofii..., s. 257.

97 M. Heidegger, Źródło dzieła sztuki, s. 35.

${ }^{98}$ M. Heidegger, Przyczynki do filozofii..., s. 122-123. 
Sprawę tę należy raczej jednak pozostawić nierozstrzygniętą, próbując stwierdzić, co jest dla Heidegger właściwym bytem.

W temacie podjętych tu rozważań warto poddać jeszcze analizie rozróżnienie na rzecz, narzędzie i dzieło sztuki, które pojawia się w dwóch ostatnich cytatach, oraz omówić kwestię ontycznego statusu języka.

\section{Dzieło sztuki i język}

W cytowanym wcześniej fragmencie wykładu Rzecz (1950) Heidegger do zbioru rzeczy zalicza obraz. Nieco inaczej sprawa wygląda w Źródle dzieła sztuki $i^{99}$. W tym tekście Heidegger próbuje określić istotę dzieła sztuki. W tym celu odróżnia je od rzeczy oraz narzędzia ${ }^{100}$. Co ciekawe, Heidegger w inny sposób niż w Pytaniu o rzecz rekonstruuje potoczne znaczenie słowa „rzecz”: „wahamy się nazwać sarnę rzeczą i źdźbło trawy, raczej to, co nieożywione w naturze i martwe przedmioty użytkowe, młotek i but"101.

Filozof odnosi się do sensu pojęcia rzecz, z którego konotacjami borykał się Kotarbiński, ostatecznie decydując się posługiwać terminem ,konkret”. W tym wykładzie Heidegger za rzecz zdaje się bowiem uznawać tylko nieożywione byty naturalne oraz artefakty użytkowe (młotek i but). Te drugie wyodrębnia jednak z szerszej grupy rzeczy, charakteryzując je jako narzędzia, które miałyby być czymś pomiędzy rzeczą a dziełem sztuki.

Heidegger, starając się opisać istotowy charakter bycia narzędzia, zastrzega, że „dopóki jedynie w ogólności uobecniamy sobie parę butów, dopóty nigdy nie doświadczamy, czym naprawdę jest bycie narzędzia narzędziem"102. W związku z tym Heidegger zwraca się ku konkretnej parze butów przedstawionej na obrazie autorstwa Vincenta Van Gogha. Filozof dostrzega w tej parze butów, między innymi, mozół powolnego stąpania, bezgłośną obawę o zapewnienie chleba, milczącą radość ponownego przetrwania biedy ${ }^{103}$. Heidegger jednak od razu zauważa, że to ujawnia nam obraz - chłopka po prostu nosi buty. To stwierdzanie nie ma jednak bynajmniej deprecjonującego wydźwięku:

Gdyby to proste noszenie było tylko noszeniem. Gdy tylko chłopka późnym wieczorem mocno, lecz zdrowo zmęczona odstawia buty, a ciemnym jeszcze brzaskiem znów po nie sięga, lub w dzień świąteczny mimochodem koło nich przechodzi, wtedy to wszystko wie bez obserwacji i rozważania ${ }^{104}$.

W dalszym toku wywodu Heidegger dochodzi do wniosku, że bycie narzędzia polega na jego przydatności, która jest ugruntowana w jego niezawodności (roz-

${ }^{99}$ Wykłady, które składają się na ten tekst, Heidegger wygłosił w roku akademickim 1935/1936, a więc równolegle do wykładów stanowiących podstawę Pytania o rzecz. Warto to odnotować, aby pokazać, jak dynamicznie kształtowała się myśl Heideggera. Zob. C. Woźniak, Martina Heideggera myślenie sztuki, Kraków 2004, s. 59.

100 Ibidem, s. 19. To rozróżnienie spotykamy także w Przyczynkach do filozofii (s. 361): „bycie potrzebuje bytu (rzecz — narzędzie — dzieło)".

${ }^{101}$ M. Heidegger, Źródło dzieła sztuki, s. 10-11.

102 Ibidem, s. 20.

103 Ibidem.

104 Ibidem, s. 21. 
budowując tym samym charakterystykę narzędzia z Bycia $i$ czasu) ${ }^{105}$. W tym momencie najważniejsze jest dla nas jednak to, że Heidegger uznaje, że bycie narzędzia zostało tu odkryte nie przez opis faktycznie istniejącego narzędzia-butów, ale poprzez obraz Van Gogha - to dzięki temu dziełu sztuki byt wkracza w nieskrytość swego bycia ${ }^{106}$. To pozwala Heideggerowi zarazem skonstatować, że istotac sztuki jest „odkładanie się w dzieło prawdy bytu (des Seienden)”, które bynajmniej nie jest żadnego rodzaju odtwarzaniem, ale odsłanianiem jego bycia ${ }^{107}$.

Nasuwa się tu pytanie, czy samo narzędzie nie mogłoby pozwolić na odkrycie prawdy swojego bycia. Ten, kto używa danego narzędzia (jak chłopka w przykładzie Heideggera), w skrytości obcuje z jego byciem. Przydatność i niezawodność narzędzia polega na tym, że gdy zajdzie potrzeba, zawsze jest ono gotowe, by człowiek mógł z niego bezwiednie skorzystać, bez jakiekolwiek namysłu. W ten sposób bycie narzędzia pozostaje w skrytości. Czy jednak gdyby podjąć namysł nad używaniem lub - mówiąc po Heideggerowsku — spróbować pomyśleć używanie, to bycie narzędzia nie odsłoniłoby się nam? Wydaje się, że byłoby to możliwe. Tym niemniej, jeśli dobrze odczytuję sens rozwiązania zaproponowanego w Drogach lasu, to Heideggerowi zależy na określeniu szczególnego sposobu ujawniania bycia przez dzieło sztuki - jest ono niejako wprost ukierunkowane na odsłanianie sensu bycia:

W sporządzeniu narzędzia, na przykład siekiery, użyty i zużyty został kamień. Znika on w przydatności. Z im mniejszym oporem rozchodzi się materiał w byciu narzędziem narzędzia, tym jest on lepszy i bardziej odpowiedni. Dzieło-świątynia natomiast [...] nie pozwala zniknąć materiałowi, lecz przede wszystkim pozwala mu wystąpić [...]: skała zaczyna dźwigać i spoczywać i w ten sposób staje się dopiero skałą, metale zaczynają błyszczeć i lśnić, barwy świecić, dźwięk brzmieć, słowo powiadać ${ }^{108}$.

Dla pytania o kształt Heideggerowskiej ontyki istotne jest to, że jego koncepcja dzieła sztuki nie wprowadza dodatkowych kategorii ontycznych, co pozwala uznać, że ma ona charakter reistyczny. Ponadto powinno się zauważyć, że w odczycie Źródło dzieła sztuki Heidegger nie formułuje ostatecznie wniosków dotyczących tego, czym jest rzecz jako rzecz. Filozof skupia się ostatecznie na narzędziu i dziele sztuki oraz różnych aspektach właściwych im sposobów bycia.

W kontekście problemu Heideggerowskiej ontyki warto jeszcze zastanowić się nad statusem języka. Jego wyjątkowa pozycja w filozofii Heideggera polega na tym, że to dzięki językowi człowiek, jako jedyny byt, może rozumieć bycie. To przekonanie jest leitmotivem całej drogi myślowej Heideggera. W wyniku zwrotu — dla stonowania ontologicznej zuchwałości człowieka - Heidegger czyni jednak ważne zastrzeżenie dotyczące związku jestestwa i języka. W Budować, mieszkać, myśleć (1951) czytamy: „Człowiek zachowuje się tak, jakby on był twórca i władcą języka, podczas gdy to język jest panem człowieka". Dla nas kluczowe jest jednak to, że w swoich późniejszych pracach Heidegger kładzie nacisk na to, aby nie traktować języka jako bytu:

105 Ibidem. Zob. W. Biemel, The Development.., s. 57.

106 M. Heidegger, Źródło dzieła sztuki, s. 21-22.

107 Ibidem, s. 22-23.

108 Ibidem, s. 30.

Studia Philosophica Wratislaviensia 13, 2018 z. 4, (C) for this edition by CNS 
Również słowo należy do tego, co daje, może nie tylko „również”, lecz przed wszystkim innym, i to nawet tak, że w słowie, w jego istocie, skrywa się to, co daje. O słowie przeto, myśląc dorzecznie, nie możemy powiedzieć: jest (Es ist), lecz: daje (Es gibt) ${ }^{109}$.

Tę uwage powinno się odnieść do koncepcji, która pojawiła się w ostatnich tekstach Heideggera, gdy mówi on o zagadce "Tego, co daje bycie i daje czas"110. Czy „To” (Es) jest tożsame z Seyn lub bez-gruntem (Ab-grund)? To pytanie, jeśli chcemy podążać tropem Heideggera, musi pozostać otwarte. Tym niemniej możemy zauważyć, że Heidegger ujmuje język podobnie jak „To” — źródłową siłę bycia, jako „To", co daje. Nie można powiedzieć, że język jest — raczej spełnia się ono w geście dawania, na przykład obdarowywania rzeczy głosem ${ }^{111}$. Dlatego też nie można uznać, że język jest bytem. Ta trudność uchwycenia jego istoty bierze się u Heideggera ze ścisłego związku języka z byciem: ,z trudem opuszcza miejsce to, co mieszka blisko źródła"112. Tak też to „nazywającą siłą słowa"113 dopuszcza byt — rzecz — w jej własne bycie, u-rzecza (be-dingt) ją ${ }^{114}$.

\section{Reistyczna orientacja Heideggerowskiej ontyki}

Zamiarem przeprowadzonych tu rozważań nie była systematyzacja Heideggerowskiej ontyki, ale wydobycie jej zastanawiającego rysu, który określam jako reistyczny (konkretystyczny) w nawiązaniu do koncepcji wypracowanej przez Tadeusza Kotarbińskiego. W filozofii Heideggera można dostrzec skłonność, aby byt utożsamiać z rzeczą rozumianą jako konkretne indywiduum. Rzeczą dla Heideggera są więc jednostkowe byty ożywione i nieożywione, naturalne i sztuczne. To one dzielą z człowiekiem wspólny obszar czasoprzestrzeni istoczenia bycia ${ }^{115}$. Czy oznacza to, że Heideggerowska ontologia wiązałaby się z ontycznym konkretyzmem? Wydaje się, że tak, ponieważ Heideggerowskie ujęcie bycia — istoczenia bytu w jego poszczególności i swoistości w relacjach z innymi bytami — kieruje raczej ku bytom jednostkowym niż bytom ogólnym i abstrakcyjnym.

Oczywiście nie możemy tracić z oczu punktu ciężkości filozofii Heideggera, która stara się wydobyć z zapomnienia problem bycia, a nie udowodnić, że to rzeczy stanowią podstawowe elementy rzeczywistości. Heidegger niejako zwrotnie próbuje odpowiedzieć, czym są rzeczy, pytając o bycie. Tym niemniej to właśnie one, nieprzypadkowo, towarzyszą temu pytaniu, co pozwala uznać, że Heideggerowska ontyka jest zorientowana reistycznie.

${ }^{109}$ M. Heidegger, Istota języka, [w:] idem, W drodze do języka, tłum. J. Mizera, Warszawa 2007, s. 174 .

110 M. Heidegger, Czas i bycie, tłum. J. Mizera, [w:] idem, Ku rzeczy myślenia, s. 25.

111 Zob. B. Swoboda, Urzeczenie rzeczy, „Hybris” 34 (2016), s. 75.

112 M. Heidegger, Źródło dzieła sztuki, s. 56.

113 Ibidem, s. 30.

114 J. Mizera, W stronę filozofii..., s. 64.

115 Warto przytoczyć tu cytat z wykładu Pytanie o rzecz (którego podtytuł to: Przyczynek do Kantowskiej nauki o zasadach transcendentalnych): „Kantowskie pytanie o rzecz otwiera wymiar, który leży między rzeczą a człowiekiem, który sięga poza rzeczy i człowieka" - M. Heidegger, Pytanie o rzecz, s. 221. 


\section{Bibliografia}

Baran B., Saga Heideggera, Kraków 1992.

Biemel W., The development of Heidegger's concept of the thing, ,Southwestern Journal of Philosophy" 3 (1980), s. 47-66.

Borowska E., Ewolucja metafizyki europejskiej w interpretacji późnego Heideggera, Warszawa 2008.

Buczyńska-Garewicz H., Miejsca, strony, okolice. Przyczynek do fenomenologii przestrzeni, Kraków 2006.

Caputo J.D., Heidegger and Aquinas: An Essay on Overcoming Metaphysics, New York 1982.

Fiut I.S., Negacja i niebyt: ujęcie systemowe G.W.F. Hegla i Martina Heideggera, Kraków 1997.

Grodziński E., Tadeusza Kotarbińskiego walka z hipostazami, „Studia Filozoficzne” 7 (1984), s. 79-93.

Heidegger M., Bycie i czas, tłum. B. Baran, Warszawa 2004.

Heidegger M., Co zwie się myśleniem?, tłum. J. Mizera, Warszawa 2000.

Heidegger M., Czas i bycie, tłum. J. Mizera, [w:] idem, Ku rzeczy myślenia, tłum. K. Michalski, J. Mizera, C. Wodziński, Warszawa 1999.

Heidegger M., „Czym jest metafizyka?”. Posłowie, tłum. K. Wolicki, [w:] idem, Znaki drogi, tłum. S. Blandzi et al., Warszawa 1999.

Heidegger M., Die Grundbegriffe der Metaphysik. Welt-Endlichkeit-Einsamkeit, Frankfurt am Main 1983.

Heidegger M., Istota języka, [w:] idem, W drodze do języka, tłum. J. Mizera, Warszawa 2007.

Heidegger M., Logik als die Frage nach dem Wesen der Sprache, Frankfurt am Main 1998.

Heidegger M., Moja droga do fenomenologii, tłum. C. Wodziński, [w:] idem, Ku rzeczy myślenia, tłum. K. Michalski, J. Mizera, C. Wodziński, Warszawa 1999.

Heidegger M., Nietzsche, t. 1, przeł. A. Gniazdowski et al., Warszawa 1999.

Heidegger M., O istocie i pojęciu psychis, tłum. J. Sidorek, [w:] idem, Znaki drogi, tłum. S. Blandzi et al., Warszawa 1999.

Heidegger M., O istocie prawdy, tłum. J. Filek, [w:] idem, Znaki drogi, tłum. S. Blandzi et al., Warszawa 1999.

Heidegger M., Podstawowe problemy fenomenologii, tłum. B. Baran, Warszawa 2009.

Heidegger M., Przyczynki do filozofii. Z wydarzania, tłum. B. Baran, J. Mizera, Kraków 1996.

Heidegger M., Pytanie o rzecz. Przyczynek do Kantowskiej nauki o zasadach transcendentalnych, tłum. J. Mizera, Warszawa 2001.

Heidegger M., Rzecz, [w:] idem, Odczyty i wykłady, tłum. J. Mizera, Kraków 2002.

Heidegger M., Zollikoner Seminare: Protokolle, Gespräche, Briefe; herausgegeben von Medard Boss, Frankfurt am Main 1987.

Heidegger M., Źródło dzieła sztuki, tłum. J. Mizera, [w:] idem, Drogi lasu, tłum. J. Gierasimiuk et al., Warszawa 1997.

Hoły-Łuczaj M., Bycie, czyli Nic. Przyczynek do lektury Heideggera, Kraków 2012. 
Inwood M., Heidegger's Dictionary, Oxford-Malden 2000.

Kamińska S., Wybrane aspekty wielorakiego znaczenia bytu i intencjonalności w ujęciu Franza Brentana i Martina Heideggera, „Argument” 2 (2013), s. 253-271.

Kotarbiński T., Elementy teorii poznania, logiki formalnej $i$ metodologii nauk, Wrocław-Warszawa-Kraków 1961.

Kotarbiński T., Epigramy, „Wiadomości” nr 15-16 (1150-1151), Londyn 14-21 kwietnia 1968, http://pauza.krakow.pl/307_4_2015.pdf.

Kotarbiński T., Fazy rozwojowe konkretyzmu, „Studia Filozoficzne” 4 (1958), s. 3-13.

Kotarbiński T., Humanistyka bez hipostaz. Próba eliminacji hipostaz ze świata pojęć nauk humanistycznych, [w:] idem, Wybór pism, t. 2, Warszawa 1958.

Kotarbiński T., O różnych znaczeniach słowa „materializm”, [w:] idem, Wybór pism, t. 2, Warszawa 1958.

Kotarbiński T., Uwagi na temat reizmu, „Ruch Filozoficzny” 12 (1931), s. 7-12.

Kotarbiński T., Zasadnicze myśli pansomatyzmu, „Przegląd Filozoficzny” 33 (1934), s. $283-294$.

Kozłowski J., O reizmie somatycznym Tadeusza Kotarbińskiego, „Zeszyty Naukowe Akademii Górniczo-Hutniczej. Prace Filozoficzne" 27 (1985), s. 28-39.

Krell D.F., Daimon Life. Heidegger and Life-Philosophy, Bloomington 1992.

Krell D.F., On the manifold of meaning of Aletheia: Aristotle, Brentano, Heidegger, „Research in Phenomenology” 5 (1975), s. 77-94.

Kwietniewska M., Res. Studium transformacji pojęcia rzeczy od Hegla do dekonstrukcji filozoficznej, Łódź 2009.

Leszczyński A., O materializmie filozoficznym T. Kotarbińskiego, „Studia Filozoficzne" 1 (1985), s. 123-131.

Levinas E., Całość i nieskończoność. Esej o zewnętrzności, tłum. M. Kowalska, Warszawa 2002.

McGrath S.J., The Early Heidegger and Medieval Philosophy: Phenomenology for the Godforsaken, Washington 2014.

Michalski K., Heidegger i filozofia wspótczesna, Warszawa 1976.

Michalski K., Stownik pojęć filozofii Martina Heideggera, [w:] idem, Zrozumieć przemijanie, Warszawa 2011.

Mizera J., W strone filozofii niemetafizycznej. Martina Heidegger droga do innego myślenia, Kraków 2006.

Richardson W.J., Heidegger, Through Phenomenology to Thought, New York 2003.

Roubach M., Being and Number in Heidegger's Thought, London 2008.

Skarga B., Tercet metafizyczny, Kraków 2009.

Swoboda B., Urzeczenie rzeczy, „Hybris” 34 (2016), s. 75-84.

Szaniawski K., Filozofia konkretu, ,Studia Filozoficzne” 3 (1976), s. 67-72.

Thomson I., Heidegger on Ontotheology: Politics and Technology of Education, Cambridge 2005.

Urbaniak R., Abstrakcja bez bytów abstrakcyjnych, „Przegląd Filozoficzny” 3 (2012), s. $7-48$.

Wodziński C., Heidegger i problem zła, Gdańsk 2007.

Woleński J., Kotarbiński, Warszawa 1990.

Woźniak C., Martina Heideggera myślenie sztuki, Kraków 2004.

Zachariasz A.L., Tylko Bóg może nas uratować, „Sofia” 11 (2011), s. 15-36. 
Is it possible that Heidegger was a reist?

\section{An attempt to reconstruct Heideggerian onticity}

\section{Summary}

The paper aims to answer the following question: does Martin Heidegger's ontology has its complement in some kind of onticity? In the attempt to reconstruct it, I show that Heidegger's concept of being is combined with the reistic theory (represented i.a. by Tadeusz Kotarbinski), according to which a being is always a thing. I argue that this is the result of the basic principles of Heideggerian being: that being is unfolding of the particularity and peculiarity of each being and that being discloses itself through the structures of time-space, and hence it can occur only in the single, unique, and concrete beings such as things, and not in ideas or general and abstract beings.

Keywords: Heidegger, onticity, reism, Kotarbinski, thing 